\title{
THE INFLUENCE OF COLLABORATIVE INFORMATION TECHNOLOGY TOOL USAGE ON NPD
}

\author{
Marion, Tucker (1); Fixson, Sebastian (2) \\ 1: Northeastern University; 2: Babson College
}

\begin{abstract}
Information Technology (IT) and the process of new product development (NPD) have become completely intertwined. From computer-aided-design (CAD) to video conferencing to traditional tools like email, the act of design, iterating and communicating with team members is touched at every point in the process by IT. Over the last ten years, new, collaborative information technology (CIT) has entered into the NPD process to make the activity of communication and team information sharing easier, more frequent, and distributed. What is not known is how these tools are influencing the design process itself. This research uses a longitudinal multi-method, ethnographic approach to deep dive into actual use cases. Our results indicate that CIT can have a substantial impact on NPD, but does not automatically alleviate traditional problems during NPD. We also find that the propagation of tools via new firms startups has developed a single tool per task paradigm, which is counter to the development of complex platforms offered by established firms. These single use tools are easily adopted but also easily discarded by development teams.
\end{abstract}

Keywords: New product development, Collaborative design, Information management

\section{Contact:}

Marion, Tucker

Northeastern University

Entrepreneurship and Innovation

United States of America

t.marion@neu.edu 


\section{INTRODUCTION}

Collaborative Information Technology (CIT) tools such as Basecamp, Slack, PBWorks, and Teamwork.com have seen enormous growth in popularity and usage over the last 15 years (Marion $e t$ al., 2016; Song et al., 2007). These tools are designed to help focus communication and input of knowledge on projects. From the perspective of a knowledge-based view (KBV) of the firm, these tools can foster faster problem solving through rapid dissemination of ideas, comments, and revisions to design.

CIT tools have augmented traditional IT tools such as computer-aided-design (CAD), product lifecycle management (PLM) systems, project management software, and desktop software such as spreadsheets (i.e., Microsoft Excel). CIT has gained in popularity among development teams, especially those that are distributed or virtual (Duranti and de Almeida, 2012). Unfortunately, few studies have investigated the project-level influence these new tools have on the new product development (NPD) process. Gilson et al. (2014) concluded that a majority of studies of IT still focus on traditional tools such as e-mail, but ignores social media and new cloud-based solutions.

This research bridges the theoretical and practical by trying to understand how these tools affect reallife projects. We seek to understand how these tools are being used, what factors enhance or inhibit their use and how they contribute to the act of design. Additionally, conceptually and theoretically we seek to understand the overall landscape of the tools themselves. How has usage changed over time as different tools have become available?

To answer these questions, we undertook a longitudinal multi-method study of CIT use among realworld project teams. Our research produces in-case as well as cross-case analyses. Additionally, we studied CIT tool introduction and propagation over the last decade to inform our research. Based on our findings, we provide theoretical insight into the use of CIT and future directions, and also provide specific managerial implications on tool deployment and observed best practices.

\section{LITERATURE REVIEW}

There are different lenses through which to look at NPD and the efficiency of the process. These include newness and project difficulty (Griffin, 2007), and components and architecture that can increase the difficulty of the engineering and component integration process (Ulrich, 1995). A third critical lens is the human side of NPD. This includes the people-related factors such as team communication, team composition, and senior management support and how they affect product development performance dimensions (Brown and Eisenhardt, 1995). Critical to this human side of NPD is collaboration among team members.

NPD team collaboration is defined as an affective process in which two or more individuals or units work together, develop a mutual understanding, share resources, and achieve collective goals (Appley and Winder, 1977; Kahn, 1996; Schrage, 1990). For example, Cooper (2001), in his discussion of the development stage, argues that it requires cross-functional collaboration as parallel actions are occurring that involve engineering, design, marketing and operations/manufacturing. In addition, this stage requires information acquisition and dissemination that necessitates team collaboration (Cooper, 2001). In a study on the role of design in the NPD process, Perks et al. (2005) found that the design and development phase includes design sketches, prototype designs, development of prototypes, and product testing. In addition, design personnel need to integrate and negotiate with other functions in this phase. Similarly, Krishnan and Ulrich (2001) indicate that during the design and development phase, decisions need to be made about issues such as the design parameters, detailed design, and the prototype plan. Yet they also emphasize that these decisions require input from various functional areas as the decisions have interdependent effects.

Integration of input from different functional areas inevitably creates friction. One mechanism that NPD teams can develop to address this friction constructively is harmony across departments. Souder $(1977 ; 1987)$ found that harmony between departments (i.e., greater collaboration) led to more successful NPD projects. Similarly, Kahn (1996) indicated that collaboration rather than simply interaction is a primary factor for NPD success. More recently, Nakata and Im (2010) provided evidence that cross-functional integration of NPD team members has a positive impact on new product performance. In other words, combining the skills, knowledge, and efforts of various functional team members leads to higher performing new products. 
A key element for successful integration of skills, knowledge, and efforts from different people are the tools they work with. As with most knowledge work, the tools for NPD have become increasingly digitized. In fact, over the past decade, the digitalization of R\&D activities has accelerated, and specifically the digitalization of collaboration has received renewed interest (Orellana, 2017). But not only the digitalization matters, but also the intensity with which the digital tools are used (Kroh et al. 2018). Because NPD has become a global activity (Eppinger and Chitkara, 2006), with teams spanning time zones and continents, CIT has become essential for information and knowledge exchange within and across the R\&D team (Carlson, 2012). Nonaka and Takeuchi (1995) noted the importance of this knowledge flow and its impact on corporate innovation (Marion et al., 2015). Carlile (2002) also noted the difficulty of knowledge management within the NPD organization, particularly when sharing this knowledge across different NPD functions (Marion at al., 2016). CIT tools are specifically designed to enhance this knowledge creation and transfer. For this reason, this research from a theoretical position adds to the knowledge-based view (KBV) of the firm.

$\mathrm{KBV}$ argues that knowledge is a resource and the firm's ability to integrate different knowledge areas and apply that knowledge to the development of new products can enhance performance (Grant, 1996; Kogut \& Zander, 1992; Nonaka, 1994; Spender, 1996). Under the KBV, the goal of CIT is to directly increase knowledge generation and sharing among team members. These tools foster virtual team communication, coordination and collaboration (Duranti and de Almeida, 2012). However, most studies of IT have focused on traditional services and product offerings such as e-mail (Gilson et al., 2014). CIT bridges traditional approaches and new forms of technology such as social networking.

We have seen substantial growth and propagation of CIT tools used for NPD and general corporate management introduced over the last 15 years. Below in Figure 1, we highlight new CIT introduced in five categories, from project management to knowledge management by year. Note the increase in total tools introduced since 2000.

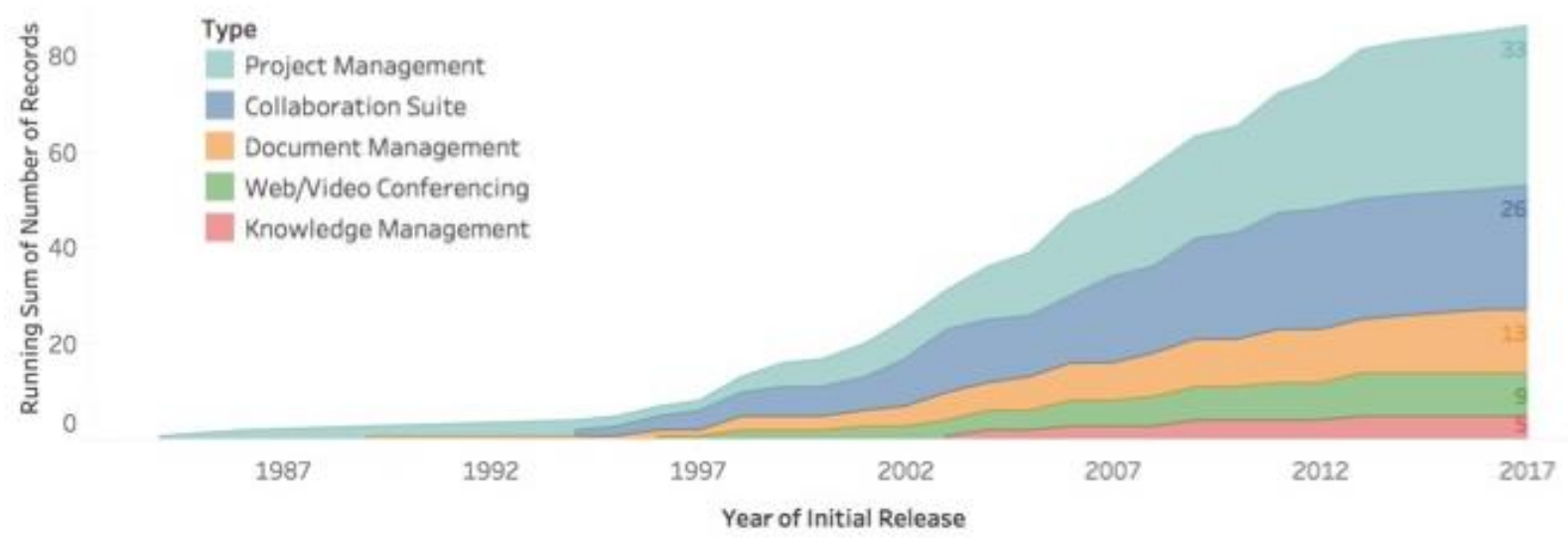

Figure 1. History of CIT tool introduction by functional type

In Figure 1, for the purpose of specifically noting web and video conferencing to illustrate growth in that category, we separated collaboration tools and video conferencing. Following prior research that has organized various IT tools into four categories of activities (Mauerhoefer, Strese, \& Brettel, 2017; Peng, Heim, \& Mallick, 2014), we condense and consider four categories for the remainder of our discussion: 1) communication IT tools (email group-ware, video conferencing), 2) product design IT tools (CAD, CAPP, simulation modelling), 3) project management IT tools (project management software), and 4) product data and knowledge management IT tools (shared parts databases). Example of these tools by category are shown in Table 1 .

\footnotetext{
${ }^{1}$ This diagram represents a cumulative summary of tools introduced primarily in the U.S. in the five specific categories.
} 
Table 1. IT tool categories and examples

\begin{tabular}{|c|c|c|c|}
\hline \multicolumn{4}{|c|}{ IT Tool Category } \\
\hline $\begin{array}{c}\text { Communication } \\
\text { Tools }\end{array}$ & $\begin{array}{l}\text { Product } \\
\text { Design }\end{array}$ & $\begin{array}{c}\text { Project } \\
\text { Management }\end{array}$ & $\begin{array}{l}\text { Product Data and } \\
\text { Knowledge } \\
\text { Management }\end{array}$ \\
\hline $\begin{array}{l}\text { Microsoft Outlook, } \\
\text { Google Gmail, Slack, } \\
\text { Yammer, Zoom }\end{array}$ & $\begin{array}{l}\text { Dassault } \\
\text { Systemes } \\
\text { Solidworks, } \\
\text { Onshape, PTC } \\
\text { Creo }\end{array}$ & $\begin{array}{l}\text { Microsoft } \\
\text { Project, } \\
\text { Teamwork.com, } \\
\text { Basecamp }\end{array}$ & $\begin{array}{l}\text { PTC ThingWorx, } \\
\text { Dassault Systemes } \\
\text { Solidworks PLM, } \\
\text { Github, GrabCAD }\end{array}$ \\
\hline
\end{tabular}

Given the array of tools available to NPD professionals, we are interested in how these CIT tools are actually being used in real projects. This brings us to our first research question:

Research Question 1: How have CIT tools affected the design process?

As previously discussed, the use of CIT tools such as wikis, blogs, and cloud-based social mediacentric platforms such as Yammer has increased dramatically over the last ten to fifteen years. In a recent study, Marion et al. (2016) noted that new tools are often commercialized via entrepreneurial new ventures. Tools such as Slack, Yammer, Basecamp and Dropbox are all entrepreneurial ventures. These complement large, established firms such as those providing digital design software (e.g. PTC and Dassault Systemes), and general software and desktop tools (e.g. Microsoft and Google) and other multi-functional platforms. Often, the entrepreneurial ventures focus on tools with a specific scope or use. For example, originally Yammer (now owned by Microsoft) was a focused communication application for users very similar to Twitter. Similarly, Zoom is a new tool focusing on providing better videoconference experiences. This is opposed to Microsoft that has cloud-based platforms and applications covering a wide array of functions and activities such document creation and sharing (SharePoint, Office 365 and Microsoft Teams), video (Skype), project management (Microsoft Project), etc. What is not known is how these different types of vendors (single use, startup applications versus established platforms) are used and integrated into the NPD process, and how this has changed overtime. Stated formally:

Research Question 2: How have CIT tools and their usage changed overtime? In the next section we review our research methodology and sample characteristics.

\section{RESEARCH METHODOLOGY}

This research is a longitudinal, multi-method investigation of the role and impact of CIT in several industry technology projects throughout their development lifecycle. The case selection follows the instructions of Yin (1994). In the cases we collect both qualitative and quantitative data, combining ethnographic participant observation, semi-structured interviews, review of archival material, and investigation of measures that the CIT use itself creates.

This research initiative into digital design and CIT has been ongoing for over ten years. The original research project began with an in-depth investigation into the use of digital design (computer-aideddesign (CAD)) tools and their influence on changing NPD methods and ultimate impact on performance. This research focused on two similar projects developed in two different periods by the same firm. ${ }^{2}$ Phase 2 of the research began in 2011 with an in-depth engagement with a growing technology company that designs and commercializes sensors and systems used in consumer, automotive and aerospace applications. This phase of the research focused specifically Characteristics of the firm in the second research phase into CIT tool use are shown below in Table 2.

\footnotetext{
2 The time periods were 2001 and 2009, during which time a whole host of CIT tools were commercialized and available to the R\&D team. This research culminated in a number of publications, including the Journal of Product Innovation Management (Fixson and Marion, 2012) and MIT Sloan Management Review (Marion et al., 2012). This research found that digital design tools have an impact on NPD, producing both positive and negative results. While providing lower cost design changes and prototyping costs, these tools can also be tempting a team to rush into detail design, or increase the number of design iterations with decreasing returns, both effects potentially leading to a phenomenon called back-loading, and as a result to an overall increase in development time and cost.
} 
Table 2. Firm characteristics

\begin{tabular}{l|l|}
\cline { 2 - 2 } Firm Type & Designer and manufacturer of electronic sensors and systems \\
\cline { 2 - 2 } $\begin{array}{l}\text { Industries } \\
\text { \# Employees }\end{array}$ & Consumer electronics, automotive, aerospace \\
\hline Annual Revenue (\$) & 600 \\
\cline { 2 - 2 } & $65 \mathrm{M}$ \\
\hline
\end{tabular}

Phase 2 of the research itself involved several stages. The first stage was an in-depth investigation into the firm's NPD process including the use and type of IT tools used during development. The next stage involved participant observation on two development projects at the firm, which began in 2014 and ended in 2017. Characteristics of the projects are shown in Table 2. In the context of the NPD process, we divide the projects into three distinct phases, Discovery, Development, and Commercialization. Discovery includes up-front activities including market investigation and conceptual development. Development consists of detailed design and engineering, and Commercialization is centered on manufacturing and market introduction. The firm in Phase 2 of the research had three phases of a defined NPD process, which align with the research framework. The final phase of the project included an in-depth research of the history of CIT tools and platforms. This research was started in 2017 and ended in 2018.

Table 3. Project characteristics

$\begin{array}{lcc} & \text { Project A } & \text { Project B } \\ \text { Start Date } & 2014 & 2015 \\ \text { Commercialization Date } & 2017 & 2018 \\ \text { Project Type } & \text { Industrial R\&D } & \text { Industrial R\&D } \\ \text { Application } & \text { Gas flow system } & \text { Gas flow system } \\ \text { Project Manager } & \text { Yes } & \text { Yes } \\ \text { \# of Team Members } & 8 & 6 \\ \text { Primary Locations } & \text { U.S., China } & \text { U.S., China } \\ \text { NPD Management } & \text { Defined, 3 Gates } & \text { Defined, 3 Gates }\end{array}$

Participant observation and interviews were used to collect qualitative, ethnographic data on the firm and development projects. Ethnography involves experiential participation by a researcher in a specific context (Marion et al., 2015). Geertz (1973) explained that ethnographic research is often used to explain the meanings of experiences in a real-world setting. Often these engagements are long-term and immersive. Fernandez (1986) noted that this approach increases the likelihood of spontaneously encountering important moments in the ordinary events of subjects' daily lives and experiencing revelatory incidents. These meanings are interpreted by the research team with the intent of identifying themes in the data and comparing information from different sources (Ware et al., 1999; Marion et al., 2015).

We followed the multi-case methodology recommendations of Yin (1994) to further diminish sources of bias within the investigation and data collection effort. These techniques included: randomization of times, places and sampling methods, attention to marginal persons and details, regular debriefing by informed colleagues, and the use of note taking to remind the participant observer to detail events seen, overheard, or experienced during fieldwork (Arnould and Wallendorf, 1994; Lincoln and Guba 1984; Marion et al., 2015). In addition, we collect data on email communication over time for both projects (Snider et al. 2017). To compare these current projects with historical data, we compare the Phase 2 sample with the two projects developed in 2001 and 2009 (Phase 1). Comparisons are noted in the next sections, which address RQ2.

\section{RESULTS AND DISCUSSION}

We find that CIT can have a positive influence on knowledge creation and information sharing among virtual team members, specifically if it supports the frequency and richness of the interaction among team members. Additionally, we find that these tools foster contribution and knowledge exchange in a 
fashion that is similar to traditional project management norms. However, we find variance between tools used. Some tools show evidence of creating the conditions for back-loading, i.e., delaying some design decisions combined with excessive, late phase iteration. This theoretical condition was the finding of Phase 1 of the research (Fixson and Marion, 2012).

\subsection{CIT usage: Research phase 2}

Project A was proposed and funded in January 2014. This project was an experiment in 'lean innovation' (Marion and Friar, 2012), meaning that the internal R\&D team was small, agile and they used outsourced partners for major pieces of the R\&D effort.

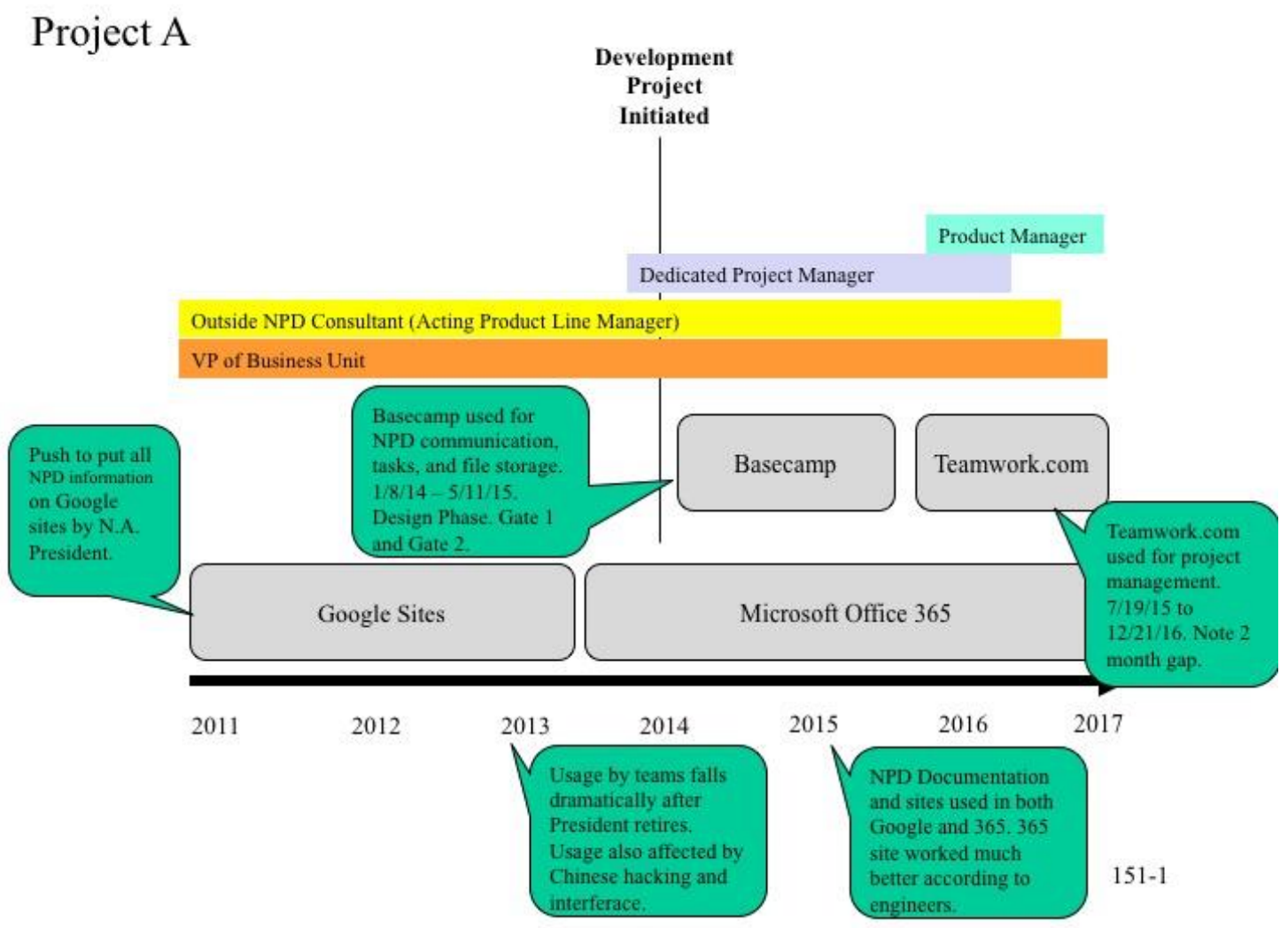

Figure 2. Project A CIT tool use timeline

During the Discovery Phase (2011 to 2014), the primary forms of communication between team members was Google Gmail and communication and posting of materials on Google Sites. At this time, a new North American President strongly advocated for all NPD activities to be managed using Google sites. This included all NPD investigations for marketing, documentation for the firm's phase gate process, as well as video communication. The active participants in the project included an outside NPD consultant acting as a product line manager as well as a business unit Vice President. The project progressed as market opportunity and product specifications were defined. In January 2014 the project was officially approved to enter into development. At the firm, this is Gate 1 , which is the Discovery phase, in which market investigation, business planning, project scoping, and initial conceptual design is performed. During this time, the firm began to experience issues and delays with Google sites. It was determined that delays in video calls and other access issues, particularly with employees in China, may be due to hacking issues with the virtual private network (VPN). Usage in Google sites for NPD collaboration and information storage waned with all team members. However, another factor that contributed to usage decline in Google sites was that after the North American President left in 2013, and his mandate for usage of Google sites was no longer enforced, the development team's usage of the platform declined dramatically. It was decided by the management team to begin migration from Google to Microsoft Office 365. This transition was completed in mid-2014.

In early 2014, the Project A was actively being developed. All information was migrated to Office 365 , including all documentation for the phase gate process. Project management tools such as 
Microsoft Excel spreadsheet action plan documents were posted, shared, and updated on SharePoint. In an interview, Project A's project manager noted that he "didn't see any significant impact in migrating from one to the other." During the development phase of the project, the acting product line manager mandated that all project design communication be centralized to Basecamp, a widely used product development management tool. This combined the ability to post files such as CAD, comment on design iterations, and have limited project management capabilities with the posting of tracked tasks. The project manager noted that the use of Basecamp and other tools helped to maintain schedules and was effective during the early phases of the project. One issue that was recurrent, were communication delays during video calls. A delay of approximately 10 minutes was experienced at the beginning of each weekly project conference call between the U.S. and Chinese teams due to connection problems. This was experienced in both Project A and Project B. Even though this technology is maturing, delays due to poor connection were seen throughout the projects.

\section{Project B}

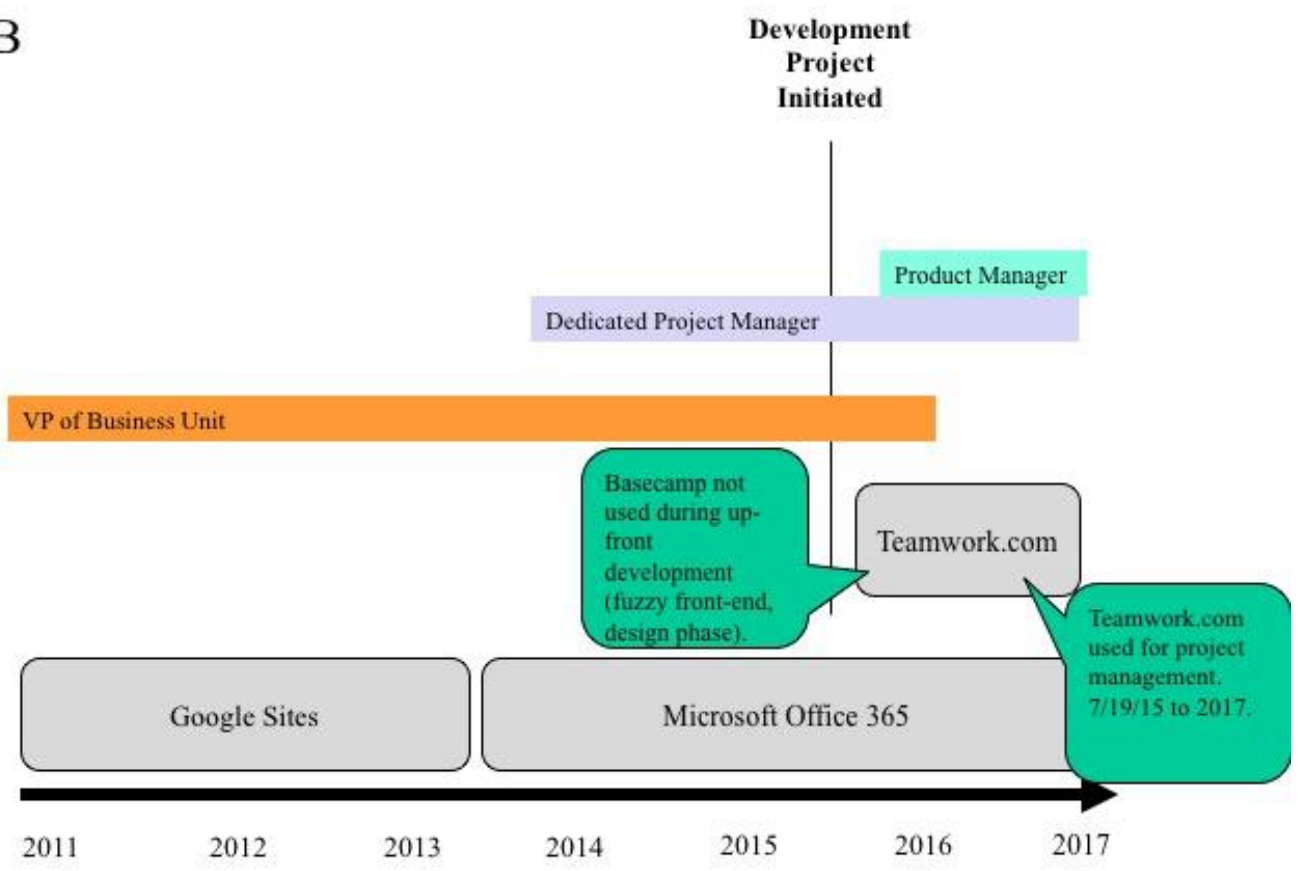

Figure 3. Project $B$ tool use timeline

Project B was initiated in 2015, as a new model companion to Project A. This project did not use Basecamp, but instead relied mostly on email (Microsoft Outlook), SharePoint, Teamwork.com and Project Libre for project management. The project manager noted the benefit of SharePoint and editing files by multiple people concurrently. The project migrated from Teamwork.com to Project Libre during the development and commercialization phases. This was due to not having the capability to do resource management. This project was continually behind schedule, and was noted for a large amount of design changes. Major CIT tools were changed mid-stream during the Development phase, which caused issues with usage among team members. Data management in this project, during Discovery and Development, was an issue in this project. Instead of one location for all filing posting and communication, at any one time three platforms were used for communication and knowledge sharing. For example, one engineer relied solely on email communication, while others focus on updating and maintaining a project management site. The chances of a missed email, some team members not being copied on a reply, or not checking on updates in project management systems creates a condition of gaps in information and knowledge shared across team members. This decreases efficiency and can lead to knowledge loss and gaps during R\&D (Meyer and Marion, 2013). 


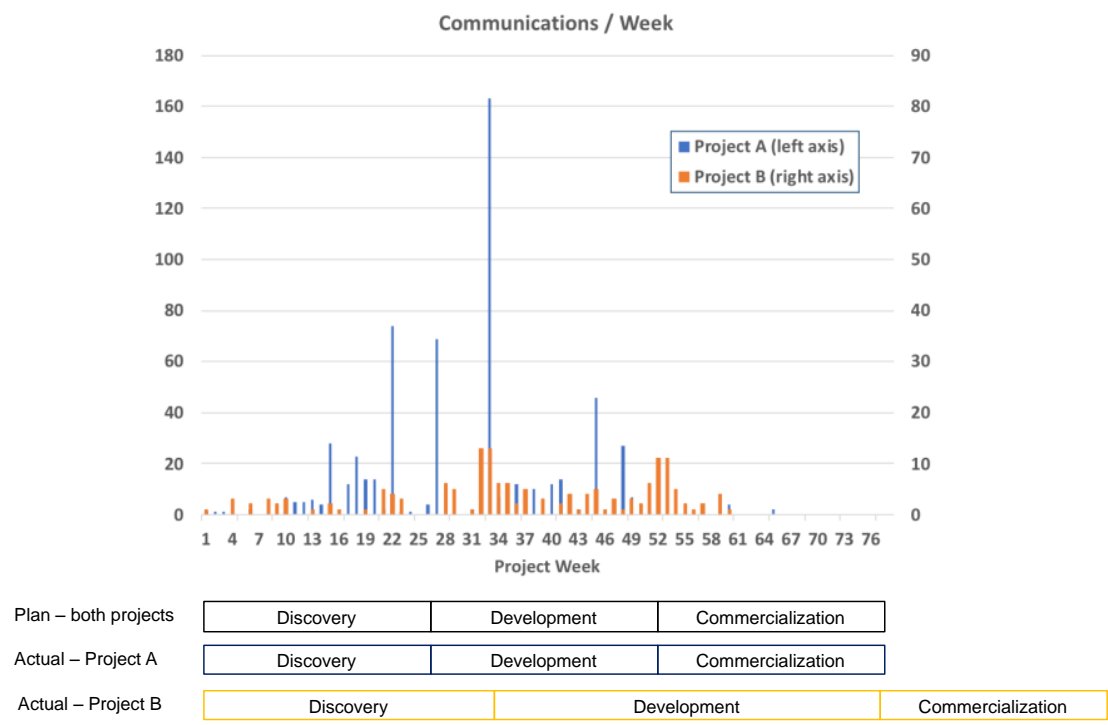

Figure 4. Frequency of communication (design and project management posts) for Projects $A$ (left, blue) and $B$ (right, orange)

In comparing the two projects, some interesting differences are noted. Project A during development committed to a single platform, Basecamp, as the primary form of design iteration and project management during Discovery and Development (the project management migrated to Teamwork.com during Commercialization). Project B used Teamwork.com during Development. Basecamp use was very active, with all members contributing to design iterations, comments, etc. This was noted by Project A's project manager. In fact, in looking at the frequency of communication, the team working on Project A was more concentrated and intense, particularly in the design phase. It should be noted that this project was $100 \%$ on-schedule during the Discovery and Development phase. The project manager and one of the engineers on Project A noted the benefit of a single place for communication and iteration. The communication frequency is similar to what should be expected in a well performing project, per project management literature. CIT tools helped facilitate this in this case example. Project B has substantially less interaction during development, and a higher post frequency in the later stages was due to increased design changes coinciding with late deliverables on important milestones. Project B experienced severe delays and cost overruns, and had a more disjointed approach to CIT, including switching project management tools during the process. This certainly had an impact on team tool usage. Also, the use of a wide variety of platforms we observed contributed to knowledge and information inefficiency during the project.

\subsection{CIT use: Research project phase 1 versus phase 2}

As noted Phase 1 of this research project investigated two projects that were developed in 2001 and 2009. Phase 2 studies projects that began in 2014 and 2015, roughly the same time distance apart. As shown in Figure 1, a wave new CIT was commercialized during this time span. In Table 3 notes the primary tools used for each of the projects.

Table 3. Historical comparison of design the CIT tools

\begin{tabular}{|c|c|c|c|c|}
\hline \multirow[b]{2}{*}{ Project Initiated } & \multicolumn{2}{|c|}{ Research Phase 1} & \multicolumn{2}{|c|}{ Research Phase 2} \\
\hline & 2001 & 2009 & 2014 & 2015 \\
\hline $\begin{array}{l}\text { Primary } \\
\text { Communication } \\
\text { Tools During } \\
\text { Development }\end{array}$ & $\begin{array}{l}\text { Email, Phone, } \\
\text { Fax }\end{array}$ & $\begin{array}{l}\text { Phone, email, } \\
\text { dedicated } \\
\text { project wiki } \\
\text { (PBWorks) }\end{array}$ & $\begin{array}{l}\text { Basecamp, email, } \\
\text { Skype }\end{array}$ & $\begin{array}{ll}\text { Email, } & \text { Skype, } \\
\text { Microsoft } & \\
\text { SharePoint } & \end{array}$ \\
\hline $\begin{array}{l}\text { Main Product } \\
\text { Design Tools }\end{array}$ & $\begin{array}{l}\text { Paper-based } \\
\text { sketches, 2D } \\
\text { Drawings, } \\
\text { SolidEdge } \\
\text { CAD }\end{array}$ & $\begin{array}{l}\text { Adobe } \\
\text { Illustrator, } \\
\text { Solidworks }\end{array}$ & $\begin{array}{l}\text { Solidworks, Matlab, } \\
\text { LabVIEW }\end{array}$ & $\begin{array}{l}\text { Solidworks, } \\
\text { ANSYS, Python, } \\
\text { LabVIEW }\end{array}$ \\
\hline
\end{tabular}




\begin{tabular}{|c|c|c|c|c|}
\hline Project & Microsoft & PBWorks & Basecamp, & Teamwork.com, \\
\hline Management Tools & Excel & & $\begin{array}{l}\text { Teamwork.com, } \\
\text { Google sites, } \\
\text { Microsoft } \\
\text { SharePoint }\end{array}$ & $\begin{array}{l}\text { Project Libre, } \\
\text { Microsoft } \\
\text { SharePoint }\end{array}$ \\
\hline
\end{tabular}

Product Data and

Knowledge

Management Tools
NA

NA
NA
NA

In looking across these four projects that span nearly 15 years, we see several trends. In main communication, we see continued consistency of email being used. We see the use of traditional telephony nearly eliminated as a primary communication method, but being replaced by video calls in the recent projects. As previously noted, there were substantial problems and delays with connection in the beginning of video calls.

Beginning in 2009, we see the introduction of collaborative cloud-based software in the form of project wikis. This cloud-based centralized form of collaboration is fundamentally different than emails. These sites pull comments and interaction from members and the community, rather than selectively pushing information to others (Marion and Schumacher, 2009). These types of sites have added general Web 2.0 technology to new product development. These wikis in the form of vendors such as Basecamp became a major form of communication by 2014, but its use was not continued for the project in 2015 due to issues noted with organized file storage and lack of detailed project management tools.

For product design tools, there is certainly a migration from traditional methods to proceeding to design in a near complete digital fashion. This includes analysis and software development. CAD is now used earlier in the process, displacing traditional, more hand-crafted elements of design. These tools are increasingly capable, and are now including innate intelligence to further automate the design process. Future trends indicate that real time analyses and artificial intelligence (AI) will have a substantial impact on the act of engineering design. ${ }^{3}$

\section{CONCLUSION AND MANAGERIAL IMPLICATIONS}

There are multiple implications for managers. The cases describe teams using tools for all the different aspects of NPD, some switching to new tools in the midst of development. As we see in our personal lives - are there simply too many tools to choose from and use? Managers and product development professionals need to balance tool use, effectiveness, and efficiency. It may be that some tasks need to be more simple, relying on more traditional methods that leverage the collaboration found in cloud-based platforms. For example, using an Office 365 Excel spreadsheet for a project management plan may be more effective than a startup's new but complex product management application.

\section{REFERENCES}

Appley, D.G. and Winder, A.E. (1977), “An evolving definition of collaboration and some implications for the world of work.” Journal of Applied Behavioral Science Vol. 13, pp. 279-291.

Arnould, E.J. and Wallendorf, M. (1994), "Market-oriented ethnography: interpretation building and marketing strategy formulation." Journal of Marketing Research, pp. 484-504.

Brown, S.L. and Eisenhardt, K.M. (1995), "Product Development: Past Research, Present Findings, and Future Directions.” Academy of Management Review, Vol. 20 No. 2, pp. 343-378.

Cardinal, L.B., Turner, S.F., Fern, M.J. and Burton, R.M. (2011), "Organizing for product development across technological environments: Performance trade-offs and priorities.” Organization Science, Vol. 22 No. 4, pp. $1000-1025$.

Carlile, P.R. (2002), A pragmatic view of knowledge and boundaries: Boundary objects in new product development. Organization science, Vol. 13 No. 4, pp. 442-455.

Carlson, M. (2012), "Powering the next generation.” PDMA Visions, No. 3, pp. 27-29.

Cooper, R.G. (2001), Winning at New Products: Accelerating the Process from Idea to Launch (3rd ed.): Basic Books.

Duranti, C.M. and de Almeida, F.C. (2012), "Is more technology better for communication in international virtual teams?" International Journal of e-Collaboration (IJeC), Vol. 8, No. 1, pp. 36-52.

Eppinger, S.D. and Chitkara, A.R. (2006), “The new practice of global product development.” MIT Sloan Management Review, Vol. 47 No. 4, p. 22.

Fernandez, J.W. (1986), Persuasions and performances: The play of tropes in culture (No. 374). Indiana University Press.

3 http://news.mit.edu/2017/reshaping-computer-aided-design-instantcad-0724 
Fixson, S.K. and Marion, T.J. (2012), "Back-loading: A potential side effect of employing digital design tools in new product development." Journal of Product innovation management, Vol. 29 No. S1, pp. 140-156.

Geertz, C. (1973), The interpretation of cultures. Basic Books, New York.

Gibson CB. and Birkinshaw J. (2004), "The antecedents, consequences, and mediating role of organizational ambidexterity." Academy of Management Journal. Vol. 47 No. 2, pp. 209-228.

Gilson, L., Maynard, M.T., Young, N., Vartiainen, M. and Hakonen, M. (2014), "Virtual teams research: 10 years, 10 themes, and 10 opportunities." Journal of Management. Vol. 41 No. 5, pp. 1313-1337.

Grant, R.M. (1996), “Toward a knowledge-based theory of the firm.” Strategic management journal, Vol. 17 No. S2, pp. $109-122$.

Griffin, A. (1997), “The Effect of Project and Process Characteristics on Product Development Cycle Time.” Journal of Marketing Research, Vol. 34 No. 1, pp. 24-35.

Kahn, K.B. (1996), "Interdepartmental integration: A definition with implications for product development performance." Journal of Product Innovation Management Vol. 13 No. 2, pp. 137-151.

Kogut, B. and Zander, U. (1992), "Knowledge of the firm, combinative capabilities, and the replication of technology." Organization science, Vol. 3 No. 3, pp. 383-397.

Krishnan, V. and Ulrich, K. (2001), "Product development decisions: A review of the literature." Management Science Vol. 47 No. 1, pp. 1-21.

Kroh, J., Luetjen, H., Globocnik, D. and Schultz, C. (2018), “Use and Efficacy of Information Technology in Innovation Processes: The Specific Role of Servitization.” Journal of Product Innovation Management, Vol. 35 No. 5, pp. 720-741.

Lincoln, Y.S., Guba, E.G. (1985), Naturalistic inquiry. Sage Publications, Inc., Beverly Hills, CA.

Marion, T.J., Reid, M., Hultink, E.J. and Barczak, G. (2016), "The Influence of Collaborative IT Tools on NPD.” Research-Technology Management, Vol. 59 No. s2, p. 47.

Marion, T.J., Eddleston, K.A., Friar, J.H. and Deeds, D. (2015), "The evolution of interorganizational relationships in emerging ventures: An ethnographic study within the new product development process." Journal of business Venturing, Vol. 30 No. 1, pp. 167-184.

Marion, T.J., Fixson, S.K. and Meyer, M.H. (2012), The Problem with Digital Design. Sloan Management Review, Summer issue.

Marion, T.J. and Schumacher, M. (2009), "Moving new venture new product development from information push to pull using web 2.0." In DS 58-3: Proceedings of ICED 09, the 17th International Conference on Engineering Design, Vol. 3, Design Organization and Management, Palo Alto, CA, USA, 24.-27.08.2009.

Mauerhoefer, T., Strese, S. and Brettel, M. (2017), “The Impact of Information Technology on New Product Development Performance.” Journal of Product Innovation Management, Vol. 34 No. 6, pp. 719-738.

Meyer, M.H. and Marion, T.J. (2013), "Preserving the integrity of knowledge and information in R\&D." Business Horizons, Vol. 56 No. 1, pp. 51-61.

Nakata, C. and Im, S. (2010), "Spurring cross-functional integration for higher new product performance: A group effectiveness perspective.” Journal of Product Innovation Management Vol. 27, pp. 554-571.

Nonaka, I. (1994), “A dynamic theory of organizational knowledge creation.” Organisation Science, Vol. 5 No. 1, pp. 14-37.

Nonaka, I. and Takeuchi, H. (1995), The knowledge-creating company: How Japanese companies create the dynamics of innovation. Oxford university press.

Orellana, S. (2017), “Digitalizing Collaboration.” Research-Technology Management, Vol. 60 No. 5, pp. 12-14.

Peng, D.X., Heim, G.R. and Mallick, D.N. (2014), "Collaborative Product Development: The Effect of Project Complexity on the Use of Information Technology Tools and New Product Development Practices." Production and Operations Management, Vol. 23 No. 8, pp. 1421-1438.

Perks, H., Cooper, R. and Jones, C. (2005), "Characterizing the role of design in new product development: An empirically derived taxonomy.” Journal of Product Innovation Management Vol. 22, pp. 111-127.

Schrage, M. (1990), Shared minds: The new technologies of collaboration. Random House, New York.

Snider, C., Škec, S., Gopsill, J.A. and Hicks, B.J. (2017), "The characterisation of engineering activity through email communication and content dynamics, for support of engineering project management.” Design Science, Vol. 3 No. 22, pp. 1-31.

Song, M.X., Berends, H., Van der Bij, H. and Weggemen, M. (2007), "The effect of IT and co-location on knowledge dissemination." Journal of Product Innovation Management Vol. 24 No. 1, pp. 52-68.

Souder, W.E. (1977), "Effectiveness of nominal and interacting group decision processes for integrating R\&D and marketing." Management Science Vol. 23 No. 6, pp. 595-605.

Souder, W.E. (1987), Managing New Product Innovations. Lexington Books, Lexington, MA.

Spender, J.C. (1996), "Making knowledge the basis of a dynamic theory of the firm." Strategic management journal, Vol. 17 No. S2, pp. 45-62.

Ulrich, K.T. (1995), "The role of product architecture in the manufacturing firm.” Research Policy, Vol. 24, pp. 419-440.

Ware, N.C., Tugenberg, T., Dickey, B. and McHorney, C.A. (1999), “An Ethnographic Study of the Meaning of Continuity Care in Mental Health Services.” Psychiatric Services, Vol. 50 No. 3, pp. 395-400.

Yin, R. (1994), Case study research: Design and methods. Beverly Hills. 